\title{
"A study of brand fidelity: Its contribution and impact on the Saudi market"
}

\begin{tabular}{|c|c|}
\hline AUTHORS & $\begin{array}{l}\text { Mohammad Rishad Faridi (iD) } \\
\text { Mohammad Naushad (i) }\end{array}$ \\
\hline ARTICLE INFO & $\begin{array}{l}\text { Mohammad Rishad Faridi and Mohammad Naushad (2021). A study of brand } \\
\text { fidelity: Its contribution and impact on the Saudi market. Innovative Marketing, } \\
\text { 17(4), 13-25. doi:10.21511/im.17(4).2021.02 }\end{array}$ \\
\hline DOI & http://dx.doi.org/10.21511/im.17(4).2021.02 \\
\hline RELEASED ON & Saturday, 23 October 2021 \\
\hline RECEIVED ON & Tuesday, 17 August 2021 \\
\hline ACCEPTED ON & Thursday, 14 October 2021 \\
\hline LICENSE & $\begin{array}{l}(c) \text { EY } \\
\text { This work is licensed under a Creative Commons Attribution } 4.0 \text { International } \\
\text { License }\end{array}$ \\
\hline JOURNAL & "Innovative Marketing " \\
\hline ISSN PRINT & $1814-2427$ \\
\hline ISSN ONLINE & $1816-6326$ \\
\hline PUBLISHER & LLC "Consulting Publishing Company "Business Perspectives" \\
\hline FOUNDER & LLC "Consulting Publishing Company "Business Perspectives" \\
\hline
\end{tabular}

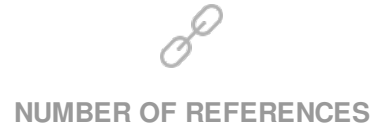

42

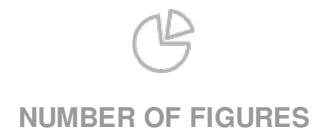

1
NUMBER OF TABLES

5

(C) The author(s) 2021. This publication is an open access article. 


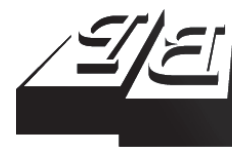

\section{BUSINESS PERSPECTIVES}

LLC "CPC "Business Perspectives" Hryhorii Skovoroda lane, 10, Sumy, 40022, Ukraine www.businessperspectives.org
Received on: $17^{\text {th }}$ of August, 2021 Accepted on: $14^{\text {th }}$ of October, 2021 Published on: $23^{\text {rd }}$ of October, 2021

( ) Mohammad Rishad Faridi, Mohammad Naushad, 2021

Mohammad Rishad Faridi, Ph.D. Assistant Professor, Marketing Department, College of Business Administration, Prince Sattam Bin Abdulaziz University Alkharj, Saudi Arabia.

Mohammad Naushad, Ph.D., Associate Professor, Management Department, College of Business Administration, Prince Sattam Bin Abdulaziz University Alkharj, Saudi Arabia. (Corresponding author)

\section{A STUDY OF BRAND FIDELITY: ITS CONTRIBUTION AND IMPACT ON THE SAUDI MARKET}

\begin{abstract}
The paradigm shift caused by disruption of traditional business models and innovation is among some factors which have propelled marketers forward-thinking in emphasizing brand fidelity. It is a novel idea and an innovative approach to understanding the impact of consumers while they demonstrate love and commitment through engagement, subconsciously or otherwise, with respect to cognition and behavior. The current study tested the components/factors of brand fidelity among Saudi consumers. The primary data for the study were collected based on the survey instrument among Saudi consumers. Overall, 446 responses were used to analyze the results. Exploratory factor analysis (EFA) coupled with confirmatory factor analysis (CFA) using IBM SPSS and AMOS were used to analyze the data. All the factors of brand fidelity, namely "accommodation/price", "accommodation/performance", "cognitive interdependence", and "derogation of alternatives", hold valid in the Saudi context with exploratory factor analysis with a factor loading of each factor above the threshold value of 0.50 , and with confirmatory factor analysis with a threshold value of more than or equal to 0.60 for all the factor loadings. The result thus obtained suggests that the brand fidelity scale is valid in the Saudi context. Saudi consumers were found to be highly loyal to their favorite brands. The findings of the study will provide inputs to the companies operating in the Saudi market for their brand-related strategy formulation. Moreover, the paper indicates undermining the power of brand fidelity in improving the bottom line through experience management.
\end{abstract}

Keywords brand fidelity, Saudi Arabia, brand commitment, brand love, consumers

JEL Classification M31, M37, O32, 039

\section{INTRODUCTION}

Consumer behavior has been of significant importance for corporations. Companies not only aim to meet the demands of customers by providing goods and services, but they also keep a close eye on their behavior toward their own and competitor' products. The elements of consumer behavior are robust, yet their loyalty is a critical factor that organizations examine as a focal point of their policy (Fournier \& Yao, 1997). Companies aim to build long-term customer loyalty. They always want to have loyal consumers. That is why, from the inception of marketing activities, marketers have been oriented toward brand equity development. As a result, brand commitment, brand loyalty, brand personality, and so forth were the primary constructs in brand management. With the advancement of brand research, brands are now evaluated with psychological and emotional perspectives. Additionally, the 'relationship factor' demonstrates the brand as a persona of being with a sense of emotion, belonging, and feelings. Therefore, management of consumer brand loyalties has been of utmost importance for companies. Customer loyalty develops the stepping stone for brand fidelity. Brand fidelity is considered as the superlative degree of customer loyalty. According to Grace et al. (2018), 
brand fidelity is the "consumer's faithfulness towards a brand partner" demonstrated with various behaviors and cognitive display. The behavior is sub-divided into accommodative/faithfulness or performance and price. At the same time, the cognitive aspects might include derogation of alternatives, attractiveness, and commitment (Grace et al., 2020). The cognitive interdependence is the feeling of "my brand" infusing love and romance to the consumer from the brand and vice versa. The emphasis on brand fidelity is more pluralistic rather than self-focus. It is a shift or transformation in consumers' perspective from "I" to "we" or "ours".

Therefore, in the present scenario of rapid disruption of traditional business models due to the advancement of technology, the culmination of brand fidelity has a critical role to play. The challenge of retaining customer loyalty and devotion is formidable. An earnest watch on consumer behavior, loyalty, and fidelity is essential for competitive advantage and formidable strategic management. Henceforth, the present study aimed to demonstrate the critical nature of brand fidelity. Saudi Arabia was chosen as the study market because it is an emerging market and a leading nation in the Middle East and North Africa (MENA) region. Saudi Arabia is often regarded as a customer-centric market. Businesses in the Kingdom of Saudi Arabia seek to earn their customer loyalty. According to an article published in the Saudi Gazette newspaper on November 26, 2018, businesses in the Kingdom of Saudi Arabia have increased their spending on customer loyalty programs. Gaining customer loyalty will assist Saudi businesses in increasing their profitability, efficiency, and effectiveness. Ultimately, it will assist Saudi businesses in contributing to the Kingdom of Saudi Arabia’s VISION 2030.

\section{LITERATURE REVIEW}

The research on consumer relationships with brands has evolved over several decades. The focus has now shifted from customer satisfaction to long-term relationship maintenance. It ranges from customer satisfaction to brand loyalty, brand commitment, brand love, and beyond (Grace et al., 2018). There is a wide range of studies accessible in the literature that concentrates on customer satisfaction e.g. Bloemer and Lemmink (1992), Back and Parks (2003), Suh and Youjae (2006), and Tu and Chih (2013). However, the shift in technology has created a shift in consumers' and businesses' priorities (Palazon et al., 2019). Now companies focus on maintaining long-term love, compassion, affection, bonding, and the relationship between customers and brands. There are multiple studies like Carroll and Ahuvia (2006), Bagozzi et al. (2017), etc., which have explored the components and arrays of love and belongingness of consumers towards the brands.

Back and Parks (2003) found that customer satisfaction significantly affects the behavioral brand loyalty mediated by attitudinal brand loyalty, including cognitive brand loyalty. As per Mathews (2019), brand loyalty is not restricted to consumer behavior, but it interfaces with various variables in forming the core of loyalty formation. It is argued that the behavior pattern of the consumer has embedded loyalty phenomenon, which tends to be more person-centered instead of brand-centered. Nevertheless, there seems a strong correlation between the consumer-centered process and the brand-centered process from which loyalty can be derived. Sharp and Sharp (1997) reiterate that a loyalty program reduces the opportunity of brand switch whereas increases brand usage, brand repurchase, etc., which reinforces brand loyalty. Brand communities can also play a vital role in building brand loyalty through communities inclined towards brand reputation. According to Muniz and O'Guinn (2001), communities are geographically widespread but socially very cautious of brand goods and services and admire a particular brand for its reputation.

Pool et al. (2018) stated that brand community commitment reflects into brand loyalty and performance of a brand or, in other words, brand outcomes. Brand commitment, as well as brand attachment, has a direct relationship with a brand community commitment. So, the brand community is directly related to brand commitment. It is argued that brand community is more brand committed unless and until it has the involvement of sustainable initiative. 
Brand love is a consortium of brand romance, brand intimacy, and brand engagement. Batra et al. (2012) argue when a consumer feels pride, speaks with esteem, believes in with enormous trust, etc., the act of not just consuming the brand regularly but by saying "my brand", the consumer falls deeply in love with the brand. This is the brighter side of the coin. Another side of the coin may be a bitter experience. Brand love may turn into brand betrayal when the marketer takes the consumer for granted. In this case, consumers may plot a vengeance strategy to defame the brand, which may have dangerous repercussions not only to the brand but also to the company performance and brand communities before intensive fall in love with a particular brand. Palazon et al. (2019) argue that self-brand connection and brand community complement each other in fostering brand love. It also mediates between brand love and brand community. Brand engagement evolves with self-concept, which is determined by personal traits, usually of the individuals or by brand communities. Brand relationships typically evolve into brand commitment, which eventually results in innate brand love. According to Das et al. (2019), brand love and relationships cannot be as intense as they are without a high level of brand commitment. Brand commitment is, indeed, the ultimate goal of brands in today's vibrant and complex marketplace. However, Rusbult et al. (2001) assert that brand commitment that is motivated by love and romantic commitment fosters an emotional attachment. Rahman et al. (2021) argue that consumers' internal and mental processes support various brand stimulus factors, with the behavioral results and outcomes reflecting the brand love. Brand love is sequenced in a systematic manner using constructs to build upon and prune outlier variables. When a consumer encounters a brand's attributes, brand love is possible (Langner et al., 2016). According to Kaufmann et al. (2016), positive brand experiences result in brand bonding, which eventually results in brand love. Moreover, brand love results in brand loyalty through repeated purchases (Ali \& Naushad, 2021). Reimann et al. (2012) argue that brand love is possible when brand satisfaction is high. As a result, positive word of mouth will spread. Consumers are prone to spread positive words, which has an exponential effect on the spread of word of mouth. As suggested by Anwar and Jalees (2020), organizations must have a customer-centric strategy to sustain the brand love effect. Brand affection can be an effective strategy for differentiating a business from its competitors. Brand love enables positive brand experiences, image, satisfaction, and word of mouth. According to Rahman et al. (2021), brand love results in four validated behavioral outcomes: brand loyalty, the ability and willingness to pay a premium price, word-of-mouth intentions, and forgiveness of brand errors. Numerous studies have been conducted to ascertain the antecedents of brand love. According to Batra et al. (2012), the primary predictor of brand love is brand quality, which contributes to the brand's positive image. Similarly, Carroll and Ahuvia (2006) argue that hedonic and self-expressive benefits are two significant validated constructs that contribute to brand loyalty. Rahman et al. (2021) examined "brand stimulus", a construct comprised of brand-endogenous variables such as functional brand uniqueness, sensory brand uniqueness, and communicative brand uniqueness. According to Fournier and Yao (1997), brand-related stimuli such as the brand logo, product, packaging, and communication all contribute significantly to consumers' affective, cognitive, and social processes.

However, academics and businesses have long investigated brand satisfaction, brand loyalty, brand commitment, and brand love. Nevertheless, what are the possibilities for the future? Grace et al. (2018) sought to address by underlining that brand loyalty flows via brand association, evaluation processes, and outcomes. Grace et al. (2018) developed a novel approach of brand fidelity that explains how consumers may demonstrate love, commitment, and trust via the integration of $\operatorname{cog}$ nitive and behavioral factors. Grace et al. (2018) propounded five different components of brand fidelity, i.e., "accommodation/forgiveness", "willingness to sacrifice", "derogation of alternatives", "cognitive interdependence", and "positive illusions". Broadly, brand fidelity represents the brand relationship maintenance of consumers. However, the studies covering the fidelity among brands are infantile. The studies, which covered the components and factors contributing to customer loyalty, love, and passion towards brands can be cited in plenty. However, the concept of brand fidelity revolves around these factors only. The original constructs of brand fidelity can be understood and explained as below. 


\subsection{Accommodation/forgiveness}

Accommodation forgiveness, as per Grace et al. (2018), "refers to the degree to which an individual is forgiving of and provides support to a brand partner in times of price/performance variations". This constructs measures the level of faithfulness shown by consumers in case of price increment or performance deplanement. This construct covers the behavioral aspects of consumers. It is more inclined towards the love, fulfillment, and supportive behavior of consumers towards brands.

\subsection{Willingness to sacrifice}

This factor describes a client's readiness to sacrifice a brand for either an unsatisfied expectation. It may be seen through the optic of forgiveness and accommodation, and so is more closely tied to the preceding notion, i.e., accommodation/forgiveness (Matear, 2014; Tucker, 2020). As per Grace et al. (2018), it refers to "the degree to which an individual is willing to make sacrifices to continue their relationship with the brand partner".

\subsection{Cognitive interdependence}

Cognitive interdependence is a mental condition defined by a pluralistic, collaborative view of the self-connected to others (Agnew et al., 1998; Grace et al., 2018). It is a degree to which one thinks to be interconnected/dependent to the one's favorite brand (Ahn \& Back, 2018; Shin \& Back, 2020). As per Grace et al. (2018), "it refers to the degree to which an individual feels at one with the brand partner and takes personal ownership of the brand".

\subsection{Derogation of alternatives}

The derogation of alternative is defined as an overestimation or leniency in respect to the current partner's attractiveness. It is also known as the derogation effect, which means that the customer takes on the role of an advocate for the brand, stressing the qualities of their selected brand partner while also being skeptical of other brands (Grace et al., 2018; Rusbult et al., 2001). As per Grace et al. (2018), "it refers to the degree to which an individual focuses on the strengths of the brand partner and the weaknesses of its competitors".

\subsection{Positive illusions}

Positive illusions refer to a situation when committed persons tend to see problematic relationships through rose-colored glasses (Murray \& Holmes, 1997). It is a kind of prejudice. Despite problems, the biased person only sees the red pictures. As per Grace et al. (2018), "it refers to the degree to which an individual has positive illusions of the brand partner, which may (or may not) reflect reality".

Since brand fidelity is indeed a novel approach proposed by Grace et al. (2018), only one research, Grace et al. (2020), is accessible in the literature that examined this concept post conceptualization by the same in 2018 . However, it is an essential concept that requires more consideration and validation in other scenarios. As a result, by applying this approach in a Saudi context, this paper tried to study this gap. Therefore, the current study will accomplish the following objectives: (1) validate the brand fidelity components in the Saudi context; (2) propose and justify brand fidelity, a novel approach to redefining the brand's intensity with a consumer; (3) investigate the effect of brand fidelity on Saudi consumers. Furthermore, this study provides an objective and referenced narrative on the significance of this concept to customers, academics, industry, and the brand itself.

\section{METHODOLOGY}

Brand fidelity is a novel concept developed by Grace et al. (2018); the instrument proposed in this study is the only available instrument in literature. For the current study, the instrument developed by Grace et al. (2020) was tested to understand the intricacy of brand fidelity in the Saudi context. The data were collected by a primary online survey developed on Google forms and administered among the consumers in Saudi Arabia. The original instrument has four different constructs, namely "accommodation/price", "accommodation/performance", "derogation of alternative", and "cognitive interdependence" to measure the brand fidelity on a six-point rating scale ranging from $1=$ "strongly agree" and $6=$ "strongly disagree" while 3 
$=$ "neutral". Ten local and international wellknown brands from varied sectors were adopted and provided to respondents to choose from their "favorite brand". There were settings done on the questionnaire that upon choosing the favorite brand, all the questions of questionnaire got customized by including the name of their favorite brand only. Overall, 500 responses were recorded, but only 446 were used for the final analysis. The rest were eliminated in the data cleaning process. Initially, the exploratory factor analysis (EFA) was conducted to know the most common factors contributing the brand fidelity among Saudi consumers. Later the confirmatory factor analysis (CFA) was done using structural equation modelling (SEM) to confirm and validate the findings of the study. Finally, the contribution of brand fidelity in the Saudi market and economy was explored and recorded from evidence-based literature.

\section{RESULTS}

\subsection{Demographic profiles and data characteristics}

Table 1 displays the demographic features of respondents. According to the data, $64.13 \%$ of those surveyed are between the ages of 20 and 30. It corresponds to the country's demographic since Saudi Arabia is known for having a younger population. While male and female respondents were represented in the survey at a ratio of 3:1. The majority of responders were unmarried, young, and college graduates. Furthermore, a single brand has evolved as a mobile and electronics brand among the ten national and global brands, which is the unchallenged global leader in the mobile and electronics industry. Surprisingly, except for one brand, barely fewer than $10 \%$ of respondents selected the rest of the brands as their favorite brands.

Table 1. Demographic profiles and data characteristics

\begin{tabular}{|c|c|c|c|c|}
\hline Favorite brand & \multicolumn{2}{|c|}{ Industry } & $\mathbf{N}$ & $\%$ \\
\hline Brand 1 & \multicolumn{2}{|l|}{ Fast food } & 3 & 0.70 \\
\hline Brand 2 & \multicolumn{2}{|l|}{ Food and beverages } & 40 & 9.00 \\
\hline Brand 3 & \multicolumn{2}{|l|}{ Banking } & 38 & 8.50 \\
\hline Brand 4 & \multicolumn{2}{|l|}{ Mobile and electronics } & 230 & 51.60 \\
\hline Brand 5 & \multicolumn{2}{|l|}{ Electronics } & 10 & 2.20 \\
\hline Brand 6 & \multicolumn{2}{|l|}{ Beverages } & 17 & 3.80 \\
\hline Brand 7 & \multicolumn{2}{|l|}{ Mobile and electronics } & 29 & 6.50 \\
\hline Brand 8 & \multicolumn{2}{|l|}{ Airline } & 30 & 6.70 \\
\hline Brand 9 & \multicolumn{2}{|l|}{ Tele-communications } & 02 & 0.40 \\
\hline Brand 10 & \multicolumn{2}{|l|}{ Automobiles } & 47 & 10.50 \\
\hline \multicolumn{3}{|l|}{ Total respondents } & 446 & 100.00 \\
\hline \multicolumn{2}{|c|}{ Characteristics } & \multicolumn{2}{|l|}{$\mathbf{N}$} & $\%$ \\
\hline \multicolumn{5}{|c|}{ Age } \\
\hline \multicolumn{2}{|l|}{ Below 20 years } & \multicolumn{2}{|l|}{88} & 19.73 \\
\hline \multicolumn{2}{|l|}{$20-30$ years } & \multicolumn{2}{|l|}{286} & 64.13 \\
\hline \multicolumn{2}{|l|}{$30-40$ years } & \multicolumn{2}{|l|}{51} & 11.43 \\
\hline \multicolumn{2}{|l|}{$41-50$ years } & \multicolumn{2}{|l|}{17} & 3.81 \\
\hline \multicolumn{2}{|l|}{51 and above } & \multicolumn{2}{|l|}{4} & 0.90 \\
\hline \multicolumn{5}{|c|}{ Gender } \\
\hline \multicolumn{2}{|l|}{ Male } & \multicolumn{2}{|l|}{327} & 73.32 \\
\hline \multicolumn{2}{|l|}{ Female } & \multicolumn{2}{|l|}{119} & 26.68 \\
\hline \multicolumn{5}{|c|}{ Marital status } \\
\hline Married & & 100 & & 22.42 \\
\hline Unmarried & & 346 & & 77.58 \\
\hline & Educati & & & \\
\hline Till grade 12/Diploma & & 66 & & 14.80 \\
\hline Graduate & & 358 & & 80.27 \\
\hline Master & & 10 & & 2.24 \\
\hline Ph.D. & & 12 & & 2.69 \\
\hline Total respondents & & 446 & & 100.0 \\
\hline
\end{tabular}


Table 2. Descriptive statistics

\begin{tabular}{|c|c|c|c|c|}
\hline Variable & AFPE & AFPR & COIN & DEOA \\
\hline Mean & 3.20 & 3.38 & 3.17 & 3.23 \\
\hline Median & 3.00 & 3.00 & 3.00 & 3.00 \\
\hline Mode & 3.00 & 3.00 & 3.00 & 3.00 \\
\hline Std. Deviation & 1.075 & 1.258 & 1.149 & 1.233 \\
\hline Variance & 1.155 & 1.584 & 1.321 & 1.519 \\
\hline Skewness & .194 & .118 & .087 & .090 \\
\hline Kurtosis & -.245 & -.620 & -.326 & -.532 \\
\hline Range & 5 & 5 & 5 & 5 \\
\hline Minimum & 1 & 1 & 1 & 1 \\
\hline Maximum & 6 & 6 & 6 & 6 \\
\hline $\mathrm{N}$ & 446 & 446 & 446 & 446 \\
\hline
\end{tabular}

Note: AFPE $=$ accommodation/price, AFPR $=$ accommodation/performance, COIN = cognitive interdependence, DEOA = derogation of alternatives.

\subsection{Descriptive statistics}

Table 2 provides the descriptive statistics. The results suggest that respondents contribute to the accommodation price, with the highest mean for AFPR $(M=3.38, S D=1.258)$. This suggests that customers are accommodating and prepared to forgive their favorite brand regardless of price differences. However, the high degree of the mean and standard deviation of DEOA $(M=3.23, S D=1.233)$ demonstrates that customers are focused on the strengths of their favored brand while keeping in mind the weaknesses of the competitors. In contrast to this, the low degree of the mean for COIN $(M=3.23$, $S D=1.233)$ indicates that customers are not able to differentiate themselves from the brand. This means that consumers are willing to take personal ownership of the brand. Overall, the descriptive statistics demonstrate that customers are more behaviorally loyal to their favorite brand than cognitively. Even more intriguing, the mean variance across all four constructs is modest. This suggests that respondents paid attention to the questions posed and that the data were of fine standards.

Table 3. Exploratory factor analysis (EFA)

\subsection{Exploratory factor analysis (EFA)}

The current study is interested in validating the brand fidelity scale among the sampled population. The exploratory factor analysis (EFA) must be performed before diving into the confirmatory factor analysis. Before beginning the exploratory factor analysis (EFA), sampling adequacy and sphericity were confirmed with Kaiser-MeyerOhlin (KMO) and Barlett's tests. The KMO values were found to be 0.894 . It was suggesting that the data is highly sufficient and justified. The sphericity test also yields significant results. The EFA was performed with Kaiser normalization and the principal component axis and orthogonal (Varimax) rotation method. Factor loading values of 0.50 and higher are considered good (Ford et al., 1986; Hinkin, 1995). This study adheres to this rule of thumb only. The original four factors were confirmed and restored by the current analysis based on Eigenvalues. However, three components of these four factors had high cross-loadings (which include COIN1, COIN2, and DEOA5), so they were dropped, and EFA was re-run. As a result, the originally developed four-factor solution was confirmed (Table 3).

\begin{tabular}{|c|c|c|c|c|c|c|}
\hline \multirow{2}{*}{ Variable } & \multirow{2}{*}{ Indicators } & \multirow{2}{*}{ Items } & \multicolumn{4}{|c|}{ Components } \\
\hline & & & 1 & 2 & 3 & 4 \\
\hline \multirow{4}{*}{$\begin{array}{l}\text { Accommodation / } \\
\text { Price }\end{array}$} & AFPR1 & $\begin{array}{l}\text { It does not bother me when } \underline{X X X} \text { increases its prices, as I will } \\
\text { always use this brand anyway }\end{array}$ & 0.775 & 0.168 & 0.271 & 0.169 \\
\hline & AFPR3 & When $X X X$ has had a price increase, it has been well justified & 0.768 & 0.054 & 0.269 & 0.214 \\
\hline & AFPR4 & $X X X$ is still well worth the money even when its prices go up & 0.757 & 0.234 & 0.146 & 0.165 \\
\hline & AFPR2 & $\begin{array}{l}\text { Regardless of what price } \mathrm{XXX} \text { is, I will always strongly } \\
\text { recommend this brand to others }\end{array}$ & 0.635 & 0.328 & 0.252 & 0.021 \\
\hline
\end{tabular}


Table 3 (cont.). Exploratory factor analysis (EFA)

\begin{tabular}{|c|c|c|c|c|c|c|}
\hline \multirow{2}{*}{ Variable } & \multirow{2}{*}{ Indicators } & \multirow{2}{*}{ Items } & \multicolumn{4}{|c|}{ Components } \\
\hline & & & 1 & 2 & 3 & 4 \\
\hline \multirow{4}{*}{$\begin{array}{l}\text { Derogation of } \\
\text { alternatives }\end{array}$} & DEOA1 & There is really no other brand like $X X X$ & 0.147 & 0.836 & 0.021 & 0.179 \\
\hline & DEOA3 & It is impossible for another brand to compete with $X X X$ & 0.251 & 0.784 & 0.078 & 0.245 \\
\hline & DEOA2 & $\begin{array}{l}\text { If asked, I would be quick to point out how superior } \underline{X X X} \text { is to } \\
\text { its competitors }\end{array}$ & 0.130 & 0.737 & 0.172 & 0.214 \\
\hline & DEOA4 & $X X X$ is faultless & 0.264 & 0.541 & 0.126 & 0.390 \\
\hline \multirow{4}{*}{$\begin{array}{l}\text { Accommodation/ } \\
\text { Performance }\end{array}$} & AFPE2 & $\begin{array}{l}\text { If } \underline{X X X} \text { experienced some problems and the brand was } \\
\text { temporarily not up to the expectation, how likely is it that } \\
\text { you would recommend this brand to others? }\end{array}$ & 0.175 & 0.146 & 0.818 & 0.002 \\
\hline & AFPE3 & $\begin{array}{l}\text { If XXX experienced some problems and the brand was } \\
\text { temporarily not up to the expectation, how likely is it that } \\
\text { you would support the brand when others were complaining } \\
\text { about it? }\end{array}$ & 0.178 & -0.005 & 0.784 & 0.167 \\
\hline & AFPE1 & $\begin{array}{l}\text { If XXX experienced some problems and the brand was } \\
\text { temporarily not up to the expectation, how likely is it that } \\
\text { you would continue to use this brand? }\end{array}$ & 0.184 & 0.077 & 0.770 & 0.081 \\
\hline & AFPE4 & $\begin{array}{l}\text { If } \underline{X X X} \text { experienced some problems and the brand was } \\
\text { temporarily not up to the expectation, how likely is it that } \\
\text { you would make excuses for the brand? }\end{array}$ & 0.230 & 0.133 & 0.635 & 0.214 \\
\hline \multirow{4}{*}{$\begin{array}{l}\text { Cognitive } \\
\text { interdependence }\end{array}$} & COIN5 & XXX is an important part of my life & 0.034 & 0.306 & 0.128 & 0.777 \\
\hline & COIN4 & $X X X$ says something about me & 0.122 & 0.060 & 0.152 & 0.760 \\
\hline & COIN3 & I would be lost without $X X X$ & 0.146 & 0.308 & 0.111 & 0.734 \\
\hline & COIN6 & $\begin{array}{l}\text { I would feel offended if someone said something bad about } \\
\text { XXX }\end{array}$ & 0.355 & 0.253 & 0.054 & 0.592 \\
\hline
\end{tabular}

\subsection{Confirmatory factor analysis (CFA)}

IBM-AMOS software was used for confirmatory factor analysis (CFA). CFA assists in validating the factor structure and determining the importance of the resulting model. Model parameters such as RMSEA, RMSR, GFI, AGFI, and NFI must be examined for structural appropriateness and acceptability (Byrne, 2016; Weston \& Gore Jr, 2006). However, for a comprehensive outlook of the goodness of fit of the model, it can be checked in three classifications, i.e., absolute fit measurement, incremental fit measurement, and parsimony fit measurement, respectively.

The root mean square error of approximation (RMSEA) is 0.062 , whereas a value of 0.08 or lesser is considered for the goodness of fit for the model (MacCallum et al., 1996; Smith \& McMillan, 2001). Therefore here, it is acceptable or fairly fit (Gaskin \& Lim, 2016; Smith \& McMillan, 2001). Further, the goodness of fit index (GFI) is 0.931, a value above 0.90 while, the adjusted goodness of fit index (AGFI) is 0.904 that too falls into more than or equal to the permissible limit (MacCallum et al., 1996; Marsh \& Balla, 1994). The last measure of absolute fit is SRMR and chi-square divided by degree of freedom, i.e., $\chi^{2} / d f$ emphasis an excellent measure of fit (Gaskin \& Lim, 2016). Here it falls into its given limits which makes together with the absolute fit (Gaskin \& Lim, 2016; Hu \& Bentler, 1999).

Additionally, the relative fit indices or the incremental fit measurements that are elucidated by the Normal Fit Index (NFI), Relative Fit Index (RFI), Incremental Fit Index (IFI), Tucker Lewis Index (TLI), and Comparative Fit Index (CFI) are 0.915, $0.896,0.945,0.932$, and 0.944 respectively, which are found to be greater and equal to the prescribed values indicating a good fit for model (MacCallum et al., 1996; Smith \& McMillan, 2001).

The next measurement check is parsimony indices, which include three parameters, i.e., respectively Parsimonious Normed Fit Index (PNFI), Parsimonious Comparative Fit Index (PCFI), Parsimonious Goodness of Fit Index (PGFI), and P close. The results for these indices are $0.747,0.771$, and 0.013 , respectively. These values reach acceptable limits; however, parsimony indices near 1 are always considered better.

The model values for all needed fit indices are inside the threshold value or rules-of-thumb and 
Table 4. Model fit indices

\begin{tabular}{|c|c|c|c|c|c|}
\hline $\begin{array}{c}\text { Statistic } \\
\text { measurements }\end{array}$ & $\begin{array}{l}\text { Absolute fit } \\
\text { measure }\end{array}$ & Threshold & Results & References & Decision \\
\hline \multirow{5}{*}{$\begin{array}{l}\text { Absolute fit } \\
\text { measurement }\end{array}$} & RMSEA & $\leq 0.08$ & 0.062 & $\begin{array}{l}\text { Gaskin and Lim (2016), Smith and McMillan } \\
(2001)\end{array}$ & Acceptable \\
\hline & $\mathrm{GFI}$ & $\geq 0.90$ & 0.931 & $\begin{array}{l}\text { MacCallum et al. (1996), Marsh and Balla } \\
(1994)\end{array}$ & Acceptable \\
\hline & AGFI & $\geq 0.90$ & 0.904 & $\begin{array}{l}\text { MacCallum et al. (1996), Marsh and Balla } \\
(1994)\end{array}$ & Acceptable \\
\hline & CMIN/DF & $\leq 3.84$ & 2.718 & Gaskin and Lim, (2016), Hu and Bentler (1999) & Excellent \\
\hline & SRMR & $<0.08$ & 0.055 & Gaskin and Lim, (2016), Hu and Bentler (1999) & Excellent \\
\hline \multirow{5}{*}{$\begin{array}{l}\text { Relative fit } \\
\text { measurement }\end{array}$} & $\mathrm{NFI}$ & $\geq 0.95$ & 0.915 & $\begin{array}{l}\text { MacCallum et al. (1996), Smith and McMillan } \\
(2001)\end{array}$ & Good Fit \\
\hline & RFI & $\geq 0.90$ & 0.896 & $\begin{array}{l}\text { MacCallum et al. (1996), Smith and McMillan } \\
(2001)\end{array}$ & Good Fit \\
\hline & $|F|$ & $\geq 0.90$ & 0.945 & $\begin{array}{l}\text { MacCallum et al. (1996), Smith and McMillan } \\
(2001)\end{array}$ & Good Fit \\
\hline & TLI & $\geq 0.90$ & 0.932 & $\begin{array}{l}\text { MacCallum et al. (1996), Smith and McMillan } \\
(2001)\end{array}$ & Good Fit \\
\hline & $\mathrm{CFI}$ & $\geq 0.90$ & 0.944 & Hu and Bentler (1999), Gaskin and Lim (2016) & Acceptable \\
\hline \multirow{3}{*}{$\begin{array}{l}\text { Parsimonious fit } \\
\text { measurement }\end{array}$} & PNFI & $\geq 0.50$ & 0.747 & Hu and Bentler (1999), Schreiber et al. (2006) & Acceptable \\
\hline & $\mathrm{PCFI}$ & $\geq 0.50$ & 0.771 & Hu and Bentler (1999), Schreiber et al. (2006) & Acceptable \\
\hline & P Close & $\geq 0.05$ & 0.013 & $\begin{array}{l}\text { Hu and Bentler (1999), Schreiber et al. (2006), } \\
\text { Gaskin (2006) }\end{array}$ & Acceptable \\
\hline
\end{tabular}

hence superior. Even if just the Chi-Square statistic, RMSEA, and its associated confidence intervals like SRMR, CFI, and one parsimony fit indicator like PNFI are reported, it is still appropriate as per the reference mentioned in Table 4. Variables including sample size, parameter estimates, and model misspecification do not affect these indexes. All of these indices are entirely fitting in the default model. Table 4 provides a comprehensive overview of CFA results statistics.

\subsection{Reliability and validity of the model}

The reliability and validity of the model are based on composite reliability and discriminant validity. The composite reliability (CR) of all the four latent constructs is greater than 0.70; however, a value above 0.60 is also acceptable but for the current model it is meeting the standardized value which is highly acceptable. The average variance extracted (AVE) is also higher than the threshold value of 0.50 . The $\operatorname{MaxR}(\mathrm{H})$ value for all the constructs is greater than 0.80 . These parameters indicate that the data has good convergent validity.

To test the discriminant validity, the square root of AVE was compared to all inter construct correlations. The square root of AVE shown on the diagonals of Table 5 is greater than the rest of the inter-construct correlations. The diagonal values are $0.714,0.744,0.744$, and 0.708 for all the constructs respectively. The correlation values between all the constructs are also found to be significant which indicates that the data/observations met the reliability criterion and are fit for analysis.

Table 5. Reliability and validity of the model

\begin{tabular}{|c|c|c|c|c|c|c|c|c|}
\hline & CR & AVE & MSV & $\operatorname{Max} R(H)$ & AFPE & AFPR & DEOA & COIN \\
\hline AFPE & 0.806 & 0.510 & 0.416 & 0.811 & 0.714 & - & - & - \\
\hline AFPR & 0.832 & 0.554 & 0.416 & 0.839 & 0.645 & 0.744 & - & - \\
\hline DEOA & 0.831 & 0.553 & 0.508 & 0.845 & 0.360 & 0.603 & 0.744 & - \\
\hline COIN & 0.799 & 0.502 & 0.508 & 0.817 & 0.402 & 0.538 & 0.713 & 0.708 \\
\hline
\end{tabular}

Note: $\mathrm{AFPE}=$ accommodation/price, AFPR = accommodation/performance, cOIN = cognitive interdependence, $\mathrm{DEOA}=$ derogation of alternatives, $\mathrm{CR}=$ convergent reliability, $\mathrm{AVE}=$ average variance extracted, $\mathrm{MSV}=$ maximum shared variance, $\operatorname{Max} R(H)=$ maximum reliability; $(H)$. 


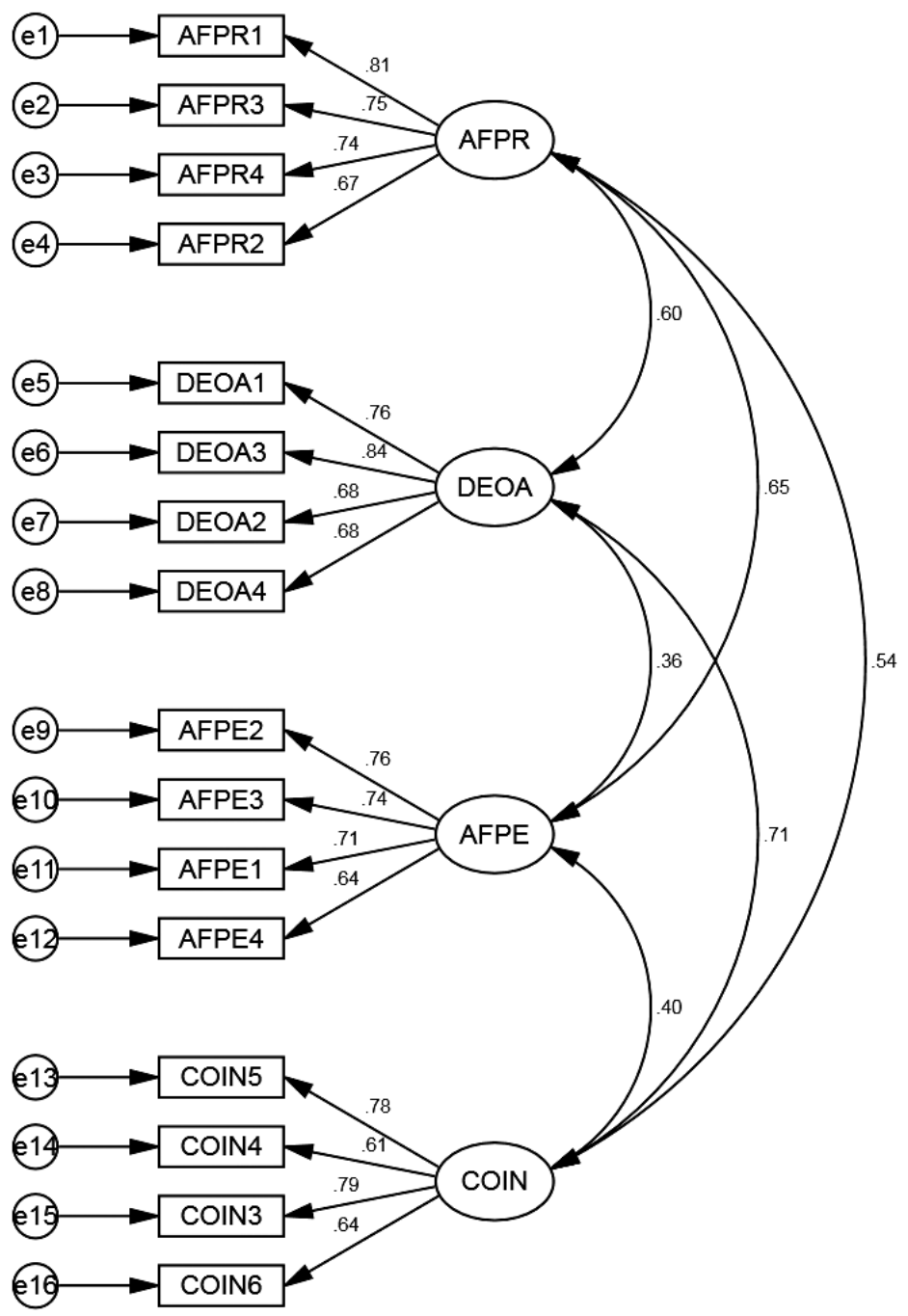

Figure 1. Structural equation model (SEM)

\subsection{Structural equation model (SEM)}

For AFPR the standard regression weights were between 0.67 and 0.81 , which are considered fit and within the desired outcomes. In the case of the second factor, i.e. AFPE, the standardized regression weights were 0.64 to 0.76 . On the other hand, the third factor, which is COIN, found regression weights between 0.64 and 0.79 . While the fourth factor, DEOA, had the standardized regression weights between 0.68 and 0.84 . Figure 1 depicts the SEM model and its regression weights.

\section{DISCUSSION}

The present study aimed to explore the level of brand fidelity among Saudi consumers. The study tried and tested the brand fidelity instrument developed by Grace et al. (2018) in the Saudi context. A primary survey was conducted among the Saudi consumers in the National Capital Region of Saudi Arabia. The data was evaluated by administering the exploratory factor analysis and confirmatory factor analysis using IBM SPSS and AMOS. The results thus confirmed that Saudi consumers are loyal to their favorite brands. All the constructs of brand fidelity found their empirical evidence and groundings among Saudi consumers.

As per Grace et al. (2018), brand fidelity from a holistic perspective is well-grounded by authentic relationships, reflecting on both market-related factors as well as product-related factors. As the intensity of a relationship becomes intimate, it passes through the journey of brand 
commitment, brand love, and finally brand fidelity. This synergy creates a profound impact on the consumer's mindset as well as improves the bonding factor of a company towards its users. Brand fidelity is reinforced by certain other variables. As Junaid et al. (2019) argue, products are either utilitarian in nature addressing functional, practical, helpful value or hedonic in nature, which reflects on the excitement, thrilling experience, and is full of fun. Smit et al. (2007) emphasized the role of brand personality in building strong intimate relationships. All well said, but marketers, even with intensive professional marketing research and with the support of sophisticated technology tools, have failed to monitor the emotional factors, which are indeed difficult to articulate and measure, as pointed out by Grace et al. (2018). For this reason, it is a breakthrough in exploring the possibilities of having a concept called brand fidelity, which seamlessly blends the behavioral aspect of consumers with cognitive "effort" towards relationship maintenance as an accurate indication of their emotional attachment. Understanding the strength, potential, and power of behavior and cognition produces a miraculous result in brand positioning.

The concept of brand fidelity is well versed with the dramatic changes witnessed by the market, especially the explosion of technology and digitalization. Brand fidelity is a social process for society, and hence it is disproved to be working in isolation. Marketers are encouraged to adopt brand fidelity to various verticals of businesses, wide use in various industries, regions, and markets. As per Grace et al. (2018), the synergy of reflecting the gamut of relationship maintenance of behaviors/cognitions, which tends to group them, helps marketers to be more strategic in decision making.

From the Middle East region perspective, particularly the Saudi Arabia market, according to Santander (2021), Saudi consumers prefer quality to quantity ( $66 \%$ of consumers value quality over price). Consumers are inclined to reputed global brands, especially luxury brands. Brand fidelity has a huge potential in the Saudi market to be used by global as well as national companies to create strong intimacy (behavioral with cognitive) and be successful. According to Grace et al. (2018), brand fidelity can only be adequate if a holistic synergistic approach is implemented rather than working in isolation. Saudi Arabia is diversifying its economy from traditionally oil-based to more towards tourism and leisure (Santander, 2021). Manufacturing, digitalization, and new technologies are all growing sectors. Therefore, there are more reasons for marketers to take advantage of brand fidelity that would yield long-term sustainable benefits to consumers and the nation as a whole. The study proves a strong brand fidelity present among Saudi consumers, which impacts companies to remain agile, be innovative and continuously showcase value. It also improves the living standard of consumers, which increases brand trust.

\section{CONCLUSION}

The current study was carried out to validate the brand fidelity components propounded by Grace et al. (2020) in the Saudi context. Moreover, the study also investigated the effect of brand fidelity on Saudi consumers. The primary data were collected from 446 respondents. The data were analyzed by applying exploratory factor analysis (EFA) and confirmatory factor analysis (CFA) using structural equation modeling (SEM) in IBM SPSS and AMOS. All the factors loadings of EFA holds valid except three with a threshold limit of 0.50 (where factor loadings $>0.50$ ). The results of EFA were validated through CFA where results were validated on absolute fit measurement, incremental fit measurement, and parsimony fit measurement, respectively.

The model adopted for the study was found to be statistically significant on all the indices adopted for the study. Whereas the measurement value of absolute fit indicators, which are SRMR and chi-square divided by degree of freedom, is found to be an excellent fit. While the values of the Normal Fit Index (NFI), Relative Fit Index (RFI), Incremental Fit Index (IFI), Tucker Lewis Index (TLI), and Comparative 
Fit Index (CFI) are $0.915,0.896,0.945,0.932$, and 0.944 respectively, which are found to be good fits. This indicates that the model adopted for the study is suitable for analysis. The regression weights of all the variables in the structural model are found to be significant. The regression weights of the variables indicate that all the components of brand fidelity, namely, "accommodation/price", "accommodation/ performance", "derogation of alternative", and "cognitive interdependence" explain the significant variation in brand fidelity among Saudi consumers. Therefore, it can be concluded that brand fidelity and its components are valid too in the Saudi context. Therefore, the findings of the study suggest the components of brand fidelity are valid in Saudi Arabia. In addition, it can be concluded that Saudi customers are loyal to their favorite brands. Moreover, brand fidelity measurement is clearly proved and validated through this empirical study. Thus, marketers and marketing research firms are encouraged to use its efficacy in predicting performance.

The implication of the study from the Saudi market perspective is substantial as it would have a profound impact by measuring the brand's performance in real time. Marketers can compare themselves to the best in their class in a specific industry and effectively track and monitor the brand's relational performance, especially to remain competitive. Marketers for the Saudi market can increase brand fidelity by focusing on emotional value and bonding with consumers' value congruence. According to Das et al. (2019), it should be surrounded by the flavor of genuine, authentic, and genuineness bonding, which also improves corporate culture. Professional consultants or academicians can use it in gamification to derive certain winning business models, which would demonstrate the degree of brand fidelity. In the long run, brand fidelity is sustainable in demonstrating brand commitment and love, discouraging competitors from engaging in advertising wars. This can be a tool to yield brand differentiation in the marketplace. Researchers are encouraged to further explore the potential of other functions of business, like financial fidelity, employee fidelity, value fidelity in the supply chain, etc. From an academic standpoint, brand fidelity topics can be incorporated into course syllabuses as contemporary studies or new marketing trends for increased familiarity. Furthermore, since brand fidelity is a novel approach, only two studies are available in the literature. It needs to be further validated with a high number of data in varied contexts.

\section{AUTHOR CONTRIBUTIONS}

Conceptualization: Mohammad Naushad.

Data curation: Mohammad Naushad.

Formal analysis: Mohammad Naushad.

Funding acquisition: Mohammad Rishad Faridi.

Investigation: Mohammad Naushad.

Methodology: Mohammad Naushad.

Project administration: Mohammad Rishad Faridi.

Resources: Mohammad Rishad Faridi.

Software: Mohammad Rishad Faridi.

Supervision: Mohammad Rishad Faridi.

Validation: Mohammad Naushad.

Visualization: Mohammad Rishad Faridi.

Writing - original draft: Mohammad Naushad.

Writing - review \& editing: Mohammad Rishad Faridi.

\section{ACKNOWLEDGMENT}

This paper was supported by the Deanship of Scientific Research at Prince Sattam Bin Abdulaziz University, Alkharj, Saudi Arabia, under the Specialized Research Grant program with Grant No. 2020/02/17342. 


\section{REFERENCES}

1. Agnew, C. R., Van Lange, P. A., Rusbult, C. E., \& Langston, C. A. (1998). Cognitive interdependence: Commitment and the mental representation of close relationships. Journal of Personality and Social Psychology, 74(4), 939-954. https://doi. org/10.1037/0022-3514.74.4.939

2. Ahn, J., \& Back, K.-J. (2018). Influence of brand relationship on customer attitude toward integrated resort brands: A cognitive, affective, and conative perspective. Journal of Travel \& Tourism Marketing, 35(4), 449-460. https://doi.org/10.1080/10548408. 2017.1358239

3. Ali, I., \& Naushad, M. (2021). Determinants of customer satisfaction in online grocery shopping. International Journal of Data and Network Science. 5(3), 383-390. http://dx.doi. org/10.5267/j.ijdns.2021.5.005

4. Anwar, A., \& Jalees, T. (2020). Brand Orientation and WOM: Mediating Roles of Brand Love. Journal of Management Sciences, 7(1), 14-30. http://dx.doi. org/10.20547/jms.2014.2007102

5. Back, K.-J., \& Parks, S. C. (2003). A brand loyalty model involving cognitive, affective, and conative brand loyalty and customer satisfaction. Journal of Hospitality \& Tourism Research, 27(4), 419435. https://doi.org/10.1177\% 2F10963480030274003

6. Bagozzi, R. P., Batra, R., \& Ahuvia, A. (2017). Brand love: Development and validation of a practical scale. Marketing Letters, 28(1), 1-14. https://doi. org/10.1007/s11002-016-9406-1

7. Batra, R., Ahuvia, A., \& Bagozzi, R. P. (2012). Brand love. Journal of Marketing, 76(2), 1-16. https://doi. org/10.1509/jm.09.0339

8. Bloemer, J. M., \& Lemmink, J. G. (1992). The importance of customer satisfaction in explaining brand and dealer loyalty. Journal of Marketing Management, 8(4), 351-363. https://doi.org/10.1080/026725 7X.1992.9964204
9. Byrne, B. M. (2016). Structural equation modeling with AMOS: basic concepts, applications, and programming (multivariate applications series). Routledge. Retrieved from https://www. routledge.com/Structural-Equation-Modeling-With-AMOSBasic-Concepts-Applications-and/ Byrne/p/book/9781138797031

10. Carroll, B. A., \& Ahuvia, A. C. (2006). Some antecedents and outcomes of brand love. Marketing Letters, 17(2), 79-89. Retrieved from https://ideas.repec.org/a/ kap/mktlet/v17y2006i2p79-89. html

11. Das, G., Agarwal, J., Malhotra, N. K., \& Varshneya, G. (2019). Does brand experience translate into brand commitment?: A mediatedmoderation model of brand passion and perceived brand ethicality. Journal of Business Research, 95, 479-490. Retrieved from https://ideas.repec.org/a/eee/ jbrese/v95y2019icp479-490.html

12. Ford, J. K., MacCallum, R. C., \& Tait, M. (1986). The application of exploratory factor analysis in applied psychology: A critical review and analysis. Personnel Psychology, 39(2), 291-314. http://dx.doi. org/10.1111/j.1744-6570.1986. tb00583.x

13. Fournier, S., \& Yao, J. L. (1997). Reviving brand loyalty: A reconceptualization within the framework of consumer-brand relationships. International Journal of Research in Marketing, 14(5), 451-472. https://doi.org/10.1016/ S0167-8116(97)00021-9

14. Gaskin, J., \& Lim, J. (2016). Model fit measures. Gaskination's StatWiki, 1-55.

15. Grace, D., Ross, M., \& King, C. (2018). Brand fidelity: A relationship maintenance perspective. Journal of Brand Management, 25(6), 577-590. Retrieved from https://ideas. repec.org/a/pal/jobman/v25y2018i6d10.1057 s41262-0180127-z.html
16. Grace, D., Ross, M., \& King, C. (2020). Brand fidelity: Scale development and validation. Journal of Retailing and Consumer Services, 52, 101908. https:// doi.org/10.1016/j.jretconser.2019.101908

17. Hinkin, T. R. (1995). A review of scale development practices in the study of organizations. Journal of Management, 21(5), 967-988. https://doi.org/10.1016/01492063(95)90050-0

18. Hu, L., \& Bentler, P. M. (1999). Cutoff criteria for fit indexes in covariance structure analysis: Conventional criteria versus new alternatives. Structural Equation Modeling: A Multidisciplinary Journal, 6(1), 1-55. https://doi. org/10.1080/10705519909540118

19. Junaid, M., Hou, F., Hussain, K., \& Kirmani, A. A. (2019). Brand love: The emotional bridge between experience and engagement, generation-M perspective. Journal of Product \& Brand Management, 28(2), 200-215. https://doi. org/10.1108/JPBM-04-2018-1852

20. Kaufmann, H. R., Loureiro, S. M. C., \& Manarioti, A. (2016). Exploring behavioural branding, brand love and brand co-creation. Journal of Product \& Brand Management, 25(6), 516-526. https://doi.org/10.1108/JPBM-062015-0919

21. Langner, T., Bruns, D., Fischer, A., \& Rossiter, J. R. (2016). Falling in love with brands: A dynamic analysis of the trajectories of brand love. Marketing Letters, 27(1), 15-26. Retrieved from https://ro.uow.edu.au/buspapers/432/

22. MacCallum, R. C., Browne, M. W., \& Sugawara, H. M. (1996). Power analysis and determination of sample size for covariance structure modeling. Psychological Methods, 1(2), 130-149. https://doi. org/10.1037/1082-989X.1.2.130

23. Marsh, H. W., \& Balla, J. (1994). Goodness of fit in confirmatory factor analysis: The effects of sample size and model parsimony. 
Quality and Quantity, 28(2), 185-217. https://doi.org/10.1007/ BF01102761

24. Matear, M. (2014). The role and nature of willingness to sacrifice in marketing relationships (Thesis). Queen's University, Canada. Retrieved from https://qspace. library.queensu.ca/bitstream/ handle/1974/8695/Matear_Maggie_201404_PhD.pdf?sequence $=1$

25. Mathews, J. (2019). A

Configurational Model of Brand Loyalty. IUP Journal of Brand Management, 16(4), 7-28. Retrieved from https://www.econbiz.de/Record/a-configurationalmodel-of-brand-loyalty-mathewsjose/10012182596

26. Muniz, A. M., \& O’Guinn, T. C. (2001). Brand community. Journal of Consumer Research, 27(4), 412-432. https://doi. org/10.1086/319618

27. Murray, S. L., \& Holmes, J. G. (1997). A leap of faith? Positive illusions in romantic relationships. Personality and Social Psychology Bulletin, 23(6), 586-604. https://doi. org/10.1177/0146167297236003

28. Palazon, M., Delgado-Ballester, E., \& Sicilia, M. (2019). Fostering brand love in Facebook brand pages. Online Information Review, 43(5), 710-727. https://doi. org/10.1108/OIR-05-2017-0175

29. Pool, A. K., Pool, M. K., \& Manjiri, H. (2018). Effect of brand community commitment on loyalty and brand outcomes in Iranian Samsung mobile users. The International Journal of Behavioral Science, 13(1), 56-67. Retrieved from https://so06.tcithaijo.org/index.php/IJBS/article/ view/68670

30. Rahman, R., Langner, T., \& Temme, D. (2021). Brand love: Conceptual and empirical investigation of a holistic causal model. Journal of Brand Management, 1-34. http://doi. org/10.1057/s41262-021-00237-7

31. Reimann, M., Castaño, R., Zaichkowsky, J., \& Bechara, A. (2012). How we relate to brands: Psychological and neurophysiological insights into consumer-brand relationships. Journal of Consumer Psychology, 22(1), 128-142. https://doi. org/10.1016/j.jcps.2011.11.003

32. Rusbult, C. E., Olsen, N., Davis, J. L., \& Hannon, P. A. (2001). Commitment and relationship maintenance mechanisms. In J. H. Harvey \& A. Wenzel (Eds.), Close Romantic Relationships: Maintenance and Enhancement (pp. 87-113). Mahwah, New Jersey: Lawrence Erlbaum Associates Publishers. Retrieved from http://www.people.vcu. edu/ jldavis/readings/Rusbult_ Olsen_Davis_Hannon_(2001).pdf

33. Santander. (2021). Tools and resources to help your company expand globally. Retrieved from www.santandertrade.com/en/portal/analyse-markets/saudi-arabia/ reaching-the-consumers

34. Schreiber, J. B., Nora, A., Stage, F. K., Barlow, E. A., \& King, J. (2006) Reporting structural equation modeling and confirmatory factor analysis results: A review. The Journal of Educational Research, 99(6), 323-338. https://doi. org/10.3200/JOER.99.6.323-338

35. Sharp, B., \& Sharp, A. (1997) Loyalty programs and their impact on repeat-purchase loyalty patterns. International Journal of Research in Marketing, 14(5), 473486. http://dx.doi.org/10.1016/ S0167-8116(97)00022-0

36. Shin, M., \& Back, K.-J. (2020). Effect of cognitive engagement on the development of brand love in a hotel context. Journal of Hospitality \& Tourism Research, 44(2), 328-350. https://doi.org/10.1177\%2F1096348019890055

37. Smit, E., Bronner, F., \& Tolboom, M. (2007). Brand relationship quality and its value for personal contact. Journal of Business Research, 60(6), 627633. https://doi.org/10.1016/j. jbusres.2006.06.012

38. Smith, T. D., \& McMillan, B. F. (2001). A Primer of Model Fit Indices in Structural Equation Modeling. Annual Meeting of the Southwest Educational Research Association. New Orleans, LA.
Retrieved from https://eric. ed.gov/?id=ED449231

39. Suh, J.-C., \& Youjae, Y. (2006). When brand attitudes affect the customer satisfaction-loyalty relation: The moderating role of product involvement. Journal of Consumer Psychology, 16(2), 145-155. https://doi.org/10.1207/ s15327663jcp1602_5

40. Tu, Y.-T., \& Chih, H.-C. (2013). An empirical study of corporate brand image, customer perceived value and satisfaction on loyalty in shoe industry. Journal of Economics and Behavioral Studies, 5(7), 469-483. https://doi. org/10.22610/jebs.v5i7.421

41. Tucker, O. (2020). Conceptualising "Willingness to Sacrifice" for Luxury Brand Acquisition. Retrieved from https://espace.curtin.edu.au/ handle/20.500.11937/83706

42. Weston, R., \& Gore Jr, P. A. (2006). A brief guide to structural equation modeling. The Counseling Psychologist, 34(5), 719-751. https://doi.org /10.1177\%2F0011000006286345 